\title{
STUDY ON STRESS PERFORMANCE AND FREE BRICKWORK HEIGHT LIMIT OF TRADITIONAL CHINESE CAVITY WALL
}

\author{
Peng Zhao, Shaoxiong Shi, Erjun Wu, Yunsheng Zhang
}

Preliminary communication

Traditional Chinese cavity wall often suffers in-plane and out-of-plane damages in natural disasters like gales and earthquakes. However, the seismic and wind resistance of the cavity wall, an enclosure structure, are seldom studied in the engineering field. Instead, the disaster prevention and relief efforts are concentrated on the structural analysis and seismic damage of the main structure. Focusing on the bricklaying methods for 2 common types of cavity walls and 1 kind of solid wall, this paper designs a special loading device and uses it to examine the in-plane and out-of-plane stress performance of cavity wall and solid wall under the horizontal load. The results show that all out-of-plane damages have resulted from the flexural-bending failure of the bend; the cavity wall has far lower out-of-plane bearing capacity than the solid wall. Moreover, the free brickwork height limits of the cavity wall under the action of earthquake and wind load are deducted respectively, in reference to the schematic diagram of the internal force of the cantilever beam and on the basis of the measured flexural-tensile strength and shear strength. It is found that the out-of-plane performance controls the brickwork limits. The authors suggest that connecting structures should be installed on each floor if the cavity wall is to be connected with the main structure.

Keywords: cavity wall; flexural-tensile strength; height limit; in-plane pressure; out-of-plane pressure; shear strength

\section{Analiza naprezanja i granice visine kod zidanja opekom tradicionalnog kineskog zida sa šupljinom}

Prethodno priopćenje

Tradicionalni kineski zid sa šupljinom često je izložen in-plane i out-of-plane oštećenjima tijekom prirodnih nepogoda poput oluja i zemljotresa. Međutim, otpor potresu i vjetru zida sa šupljinom, zatvorene konstrukcije, rijetko se proučava. Umjesto toga, sprječavanje najgorega i napori za stvaranje sigurnosti koncentrirani su na konstrukcijsku analizu i štete od potresa glavne konstrukcije. Usmjerivši se na tehnike zidanja kod 2 uobičajena tipa zida sa šupljinom i 1 vrste punog zida, u ovom se radu konstruira specijalni uređaj za opterećenje i koristi za ispitivanje in-plane i out-of-plane naprezanja zida sa šupljinom i punog zida pod horizontalnim opterećenjem. Rezultati pokazuju da su sva out-of-plane oštećenja rezultat nedovoljne izdržljivosti na savijanje; zid sa šupljinom ima daleko nižu out-of-plane nosivost nego puni zid. Uz to, postoje znatna ograničenja visine kod zidanja zida sa šupljinom zbog potresa i snažnih vjetrova, s obzirom na shematski dijagram interne sile konzolnog nosača i na osnovu izmjerene savojno-vlačne i smične čvrstoće. Ustanovljeno je da out-of-plane ponašanje određuje granice zidanja opekom. Autori predlažu da se na svakom katu postave vezne konstrukcije ako zid sa šupljinom treba biti povezan s glavnom konstrukcijom.

Ključne riječi: granica visine; in-plane tlak; out-of-plane tlak; savojno-vlačna čvrstoća; smična čvrstoća; zid sa šupljinom

\section{Introduction}

Traditional Chinese buildings are masterpieces of architecture art, structure and construction. As a highlight in the history of world architecture, these buildings have promoted the advancement of global architectural technology and manifested the inestimable value of ancient Chinese culture [1-3]. Hence, the maintenance and protection of ancient buildings and the representation of ancient architectural forms are in the limelight of the research of architectural technology $[4,5]$. In both ancient and antique buildings, the brick wall is a critical loadbearing or enclosure component. The status quo of heritage buildings can be preserved only if the wall is safe and sound [6-8]. Unfortunately, damaged walls are commonplace in ancient buildings owing to typhoons and earthquakes. The situation is particularly serious for buildings with cavity walls. With poor integrity and low bearing capacity, the cavity wall suffers heavy damages. In the case of an earthquake, the heritage buildings with cavity walls are bound to suffer major losses [9, 10].

The seismic performance of the cavity wall was firstly studied the 1970s in China. The research pointed out that the shear strength of the wall was half of that of solid wall, but failed to provide the brickwork height limit [11-13]. At present, the cavity wall design and construction of heritage buildings still follow the ancient technologies and standards. This calls for scientific, systematic theories on research, design and construction technology $[14,15]$. One of the most practical ways to prevent the loss of cultural relics caused by cavity wall damages lies in evaluating the cavity wall performance of ancient and antique buildings, determining the height limits of the wall, and proposing rational construction measures according to the evaluation results [16, 17]. For the protection, design and construction of ancient and antique buildings with cavity walls, it is of great practical significance and engineering guidance to study the out-ofplane and in-plane stress performance of the cavity wall.

Focusing on the bricklaying methods for 2 common types of cavity walls and 1 kind of solid wall, this paper experimentally studies the internal force and deformation performance of these walls under in-plane and out-ofplane horizontal loads, respectively, analyzes the effect of bricklaying method, height-thickness ratio and heightwidth ratio on the in-plane and out-of-plane bearing capacity of the cavity wall, and arrives at the allowable brickwork height limits of the cavity wall under different seismic intensities and wind loads. The results lay an important theoretical basis for the protection, assessment, design and construction of ancient and antique buildings with cavity walls, and provide reference for the future research on the out-of-plane performance of the wall.

\section{Experimental methods}

\subsection{Design and production of specimens}

\subsubsection{Experimental materials}

Grey bricks used in this study were bought from Changzhou Long Yun Antique Building Materials Corporation Ltd. Their physical properties are shown in Tab. 1. 
Table 1 Physical property of grey bricks

\begin{tabular}{|l|c|}
\hline \multicolumn{1}{|c|}{ Property index } & Value \\
\hline Original size & $206 \times 90 \times 25 \mathrm{~mm}$ \\
\hline Bulk density & $1747 \mathrm{~kg} / \mathrm{m}^{3}$ \\
\hline Compressive strength & $14,47 \mathrm{MPa}$ \\
\hline
\end{tabular}

According to written records [18], the ancient masonry mortar has the same compressive strength with the M5 mortar. Thus, the mix ratio of the mortar is set as 1:5.6:1.15. The sand is pre-filtered through a sieve (mesh size: $2.36 \mathrm{~mm}$ ). The mortar thickness in the wall is $10 \mathrm{~mm}$. The mortar specimens are produced under natural curing conditions. The wall mechanics test is carried out when the compressive strength of the specimens reaches about $5 \mathrm{MPa}$. The strengths of the specimens are shown in Tab. 2.

\subsubsection{Parameters of out-of-plane specimens}

Two common bricklaying methods for the cavity wall are selected (Fig. 1): the cavity wall with header, and the cavity wall without header. The "header" stands for a brick laid flat. By contrast, a brick laid vertically is called a "shiner". The cavity wall with header is constructed by laying a layer of headers between every $1 \div 3$ layers of shiners (Fig. 1(a)), while the cavity wall without header is built by laying shiners only (Fig. 1(b)). The third bricklaying method is used to construct the solid wall. Specifically, each layer of bricks is laid by inserting a rowlock between two stretchers.

a)
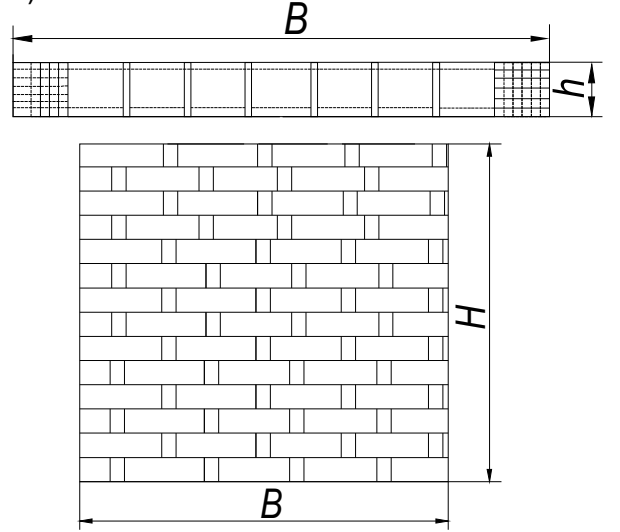

(a) Building method I: planar graph and elevation graph (b) Building method II: planar graph and elevation graph Figure 1 Two building methods of specimen and parameters are presented in Tab. 3 .

\subsubsection{Parameters of in-plane specimens} parameters are shown in Tab. 4.

\subsection{Experimental loading apparatus \\ 2.2.1 Out-of-plane loading apparatus} respectively.

b)
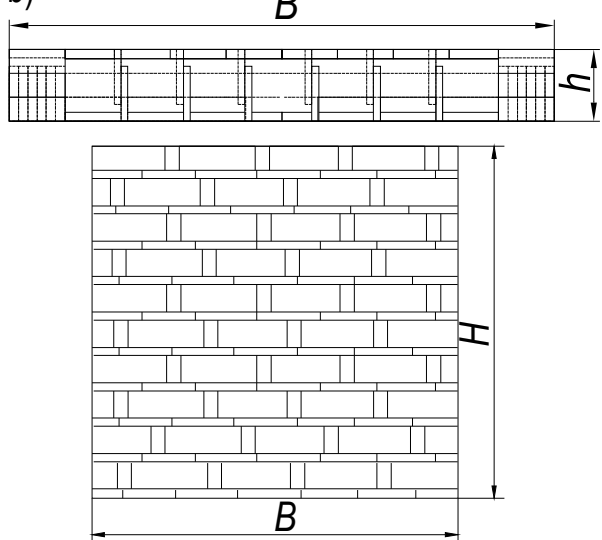

9 full-scale (1:1) specimens of different heightthickness ratios and height-width ratios are chosen to discuss the construction of the walls. The specific sizes

Four in-plane specimens are designed whose

The horizontally distributed load resulting from the wind load and earthquake appears vertically along the wall [19-21]. Simulating such a load in the test is no easy feat. If surface loading is applied, it is difficult to maintain the uniform contact between the loading surface and the horizontally deformed wall, which will distort the subsequent loads. The conventional jack loading, however, lacks sufficient control accuracy under small load value of each level because the out-of-plane bearing capacity is relatively low and the rated load of the jack is far greater than the load required [22]. In order to maintain high control accuracy, the project team designs a special loading device, divides the distributed surface loads into horizontal linear loads at an interval of $0.5 \mathrm{~m}$ along the vertical direction, and applies the horizontal loads manually with steel blocks. The loading device and the loading method are shown in Fig. 2 and Fig. 3,

Table 2 Strength of mortar blocks under the same curing conditions

\begin{tabular}{|l|c|c|c|c|c|c|c|c|c|}
\hline Number of wall & W1A & W1B & W1C & W2A & W2B & W2C & W3A & W3B & W3C \\
\hline Mortar strength (MPa) & 5,71 & 5,97 & 4,83 & 5,05 & 5,45 & 5,24 & 5,21 & 4,79 & 5,83 \\
\hline
\end{tabular}

Table 3 Design of Out-of-plane specimens

\begin{tabular}{|c|c|c|c|c|c|}
\hline Number of specimens & Breadth $B(\mathrm{~mm})$ & Height $H(\mathrm{~mm})$ & Thickness $h(\mathrm{~mm})$ & Height to thickness ratio $H / h$ & Height to breadth ratio $H / B$ \\
\hline W1A & 2000 & 2000 & 206 & 9,70 & 1,00 \\
\hline W1B & 2000 & 3000 & 206 & 14,56 & 1,50 \\
\hline W1C & 3000 & 2000 & 206 & 9,70 & 0,67 \\
\hline W2A & 2000 & 2000 & 270 & 7,41 & 1,00 \\
\hline W2B & 2000 & 3000 & 270 & 71,11 & 1,50 \\
\hline W2C & 3000 & 2000 & 270 & 6,41 & 0,67 \\
\hline W3A & 2000 & 2000 & 300 & 10 & 1,00 \\
\hline W3B & 2000 & 3000 & 300 & 6,67 & 1,50 \\
\hline W3C & 3000 & 2000 & 300 & 0,67 \\
\hline
\end{tabular}

Note: 1, 2 stand for the building method I for the cavity wall and building method II for the cavity wall respectively, 3 for the building method for the solid wall; there are three specimens for each group, A, B, C show the impacts of height to breadth ratio and height to thickness ratio. The length of the two solid ends is $200 \mathrm{~mm}$. 


\begin{tabular}{|c|c|c|c|c|}
\hline \multicolumn{1}{|c|}{ Table 4 Design of in-plane specimens } \\
\hline Number of specimens & Breadth $B(\mathrm{~mm})$ & Height $H(\mathrm{~mm})$ & Thickness $h(\mathrm{~mm})$ & Height to thickness ratio $H / h$ \\
\hline K1 & 2000 & 1000 & 206 & 4,85 \\
\hline K2 & 3000 & 1000 & 206 & 4,85 \\
\hline K3 & 2000 & 1000 & 270 & 3,70 \\
\hline S1 & 2000 & 1000 & 206 & 4,85 \\
\hline
\end{tabular}

Note: $\mathrm{K} 1, \mathrm{~K} 2$ are cavity bricks; $\mathrm{K} 3$ is cavity bricks laid flat and $\mathrm{S} 1$ is the solid wall.

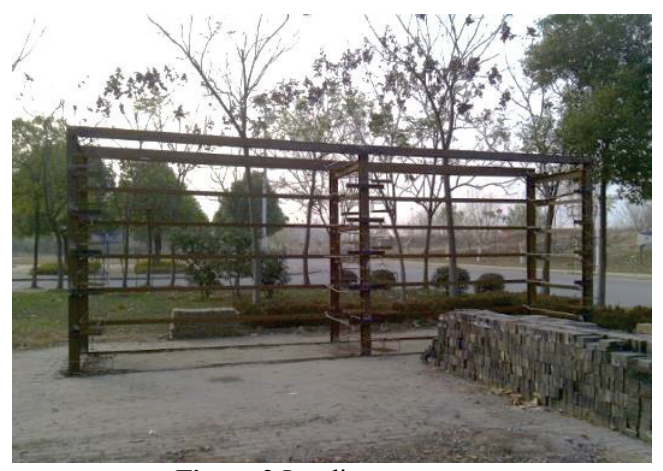

Figure 2 Loading apparatus

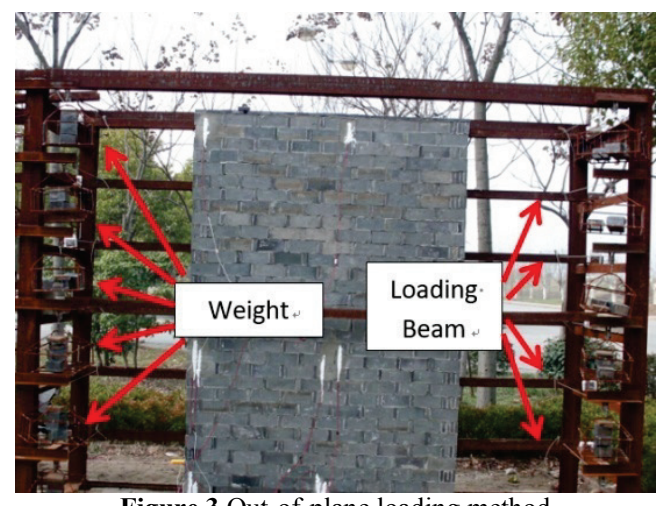

Figure 3 Out-of-plane loading method

\subsubsection{In-plane loading apparatus}

In view of the large load of the in-plane test, the existing out-of-plane loading frame is modified for inplane loading (Fig. 4). The loading device is a jack.

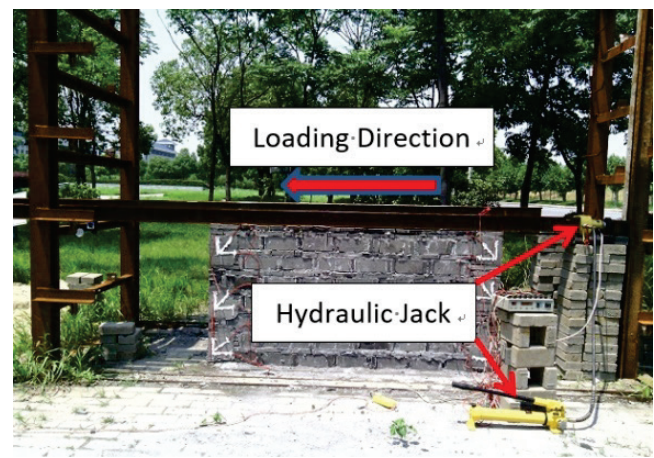

Figure 4 In-plane loading apparatus
The in-plane wall mainly withstands the horizontal seismic action [23-25]. As an inertial force, the seismic action is related to the mass distribution and is thus uniformly applied across the wall. The cavity wall is empty in the middle and solid on both ends. Unlike the solid wall, the cavity wall features uniform load distribution under in-plane loading: most of the loads are borne by the solid wall section at the loading end. As the load is transferred to the other end, the cavity wall section may undergo local instability, resulting in test failure. Thus, a special loading measure is badly needed. The project team comes up with the following measures: level up the top of the wall with epoxy resin, paste the capping beam, and apply the jack's horizontal loads on the beam. Since the steel beam is much stiffer than the cavity wall, the horizontal force can be applied evenly on the top of the wall via the epoxy resin bonding surface.

\subsection{Test contents \\ 2.3.1 Out-of-plane experiment}

In this test, the quasi-static method is adopted to simulate the seismic action applied onto the wall during an earthquake. Before the wall is cracked, the load is controlled and applied level by level. Each level of load is applied in one loading cycle. The magnitude of load level is reduced when the wall is about to crack. The moment of cracking signifies that the wall has reached the ultimate load. The loading blocks apply load onto the wall via the beams of the loading frame. The number of loading blocks is recorded in the test.

\subsubsection{Loading system}

During the test, the load is applied level by level. The theoretical cracking load of the wall is calculated in advance. In the out-of-plane loading test, the load is increased by $49 \mathrm{~N}(5 \mathrm{~kg})$ in each level; after reaching $80 \%$ of the designed limit load, the load is increased by $9.8 \mathrm{~N}$ in each level. The number of weights grows with the load (Tab. 5). In the in-plane loading test, the load is increased by $4 \mathrm{kN}$ in each level; after reaching $80 \%$ of the designed limit load, the load is increased by $1 \mathrm{kN}$ in each level (Tab. 6).

Table 5 Loading of out-of-plane specimens

\begin{tabular}{|c|c|c|c|c|c|c|c|c|c|}
\hline \multirow{2}{*}{ Loading level } & \multicolumn{9}{|c|}{ Number of specimens } \\
\hline & W1A & W1B & W1C & W2A & W2B & W2C & W3A & W3B & W3C \\
\hline $98 \mathrm{~N}$ & 0 & 0 & 0 & 0 & 0 & 0 & 2 & 1 & 2 \\
\hline $49 \mathrm{~N}$ & 4 & 3 & 5 & 5 & 4 & 6 & 3 & 3 & 3 \\
\hline $9.8 \mathrm{~N}$ & 4 & 3 & 5 & 4 & 3 & 4 & 6 & 6 & 8 \\
\hline
\end{tabular}

Table 6 Loading of in-plane specimens

\begin{tabular}{|c|c|c|c|c|}
\hline \multirow{2}{*}{ Loading level } & \multicolumn{3}{|c|}{ Number of specimens } \\
\cline { 2 - 4 } & $\mathrm{K} 1$ & \multicolumn{2}{|c|}{$\mathrm{K} 2$} & 5 \\
\hline $\mathrm{S} 1$ & 5 & 5 & 7 \\
\hline $1 \mathrm{kN}$ & 3 & 3 & 2 \\
\hline
\end{tabular}




\section{Results and discussions}

\subsection{The building height limit under the impact of earthquakes}

The inertial force of the earthquake is correlated with mass. The seismic action is expressed as a horizontal uniform force (Eq. (1)) because the mass of the wall is evenly distributed along the vertical direction. The simple diagram for calculation shown in Fig. 5. Eq. (2) is the calculation formula of the bending moment of the wall under seismic action.

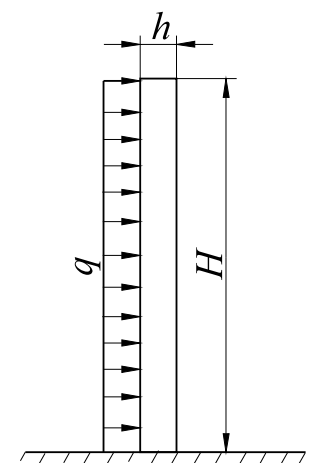

Figure 5 Calculation diagram of the wall

$$
\begin{aligned}
& q=\frac{m m a g}{H}, \\
& M=\frac{1}{2} q H^{2} .
\end{aligned}
$$

As the maximum permitted bending moment $[M]$ can be obtained by the experiment data, the wall should meet the condition: $M<[M]$.

$H=\sqrt{\frac{2[M]}{q}}$,

where $m$ is the mass of the wall $(\mathrm{kg}) ; g$ is the gravitational acceleration $\left(\mathrm{m} / \mathrm{s}^{2}\right) ; H$ is the height of the wall $(\mathrm{m}) ; \alpha$ is the horizontal seismic impact coefficient (see the Code for Seismic Design of Buildings [24]); $\gamma=1.3$ is the partial coefficient of seismic action; $M$ is the bending moment under seismic action $(\mathrm{kN} \cdot \mathrm{m}) ;[M]$ is the allowable bending moment obtained based on the test data.

The test results of each group are substituted into Eq. (2) to get the brickwork height limits of the wall under the action of earthquakes of different intensities. The calculated results are shown in Tab. 7 .

As can be seen from Tab. 7, when the height of the wall is the same, the wall is less likely to hold together as the width expands and the proportion of cavity section grows. For cavity wall without header, the average strength and allowable height are reduced significantly by $25 \%$; for cavity wall with header, the two parameters are increased to a certain extend. Considering the discretization of mortar, it is safe to conclude that the width has a minimal effect on the mechanical properties of the wall when headers are used.

Comparing the different bricklaying methods, the two types of cavity walls have basically the same allowable height. Since the seismic fortification intensity of most regions in China is below 7 , the height limit is set as $4 \mathrm{~m}$ without any lateral constraint, that is, the single-layer cavity wall will not suffer out-of-plane collapse when an earthquake of the fortification intensity takes place.

\subsection{Building height limits under different wind loads}

The cavity wall may also get damaged under the action of wind. Thus, it is necessary to deduct the brickwork height limits under different wind pressures.

For general buildings, the standard wind load vertically applied onto the building surface is calculated as follows:

$W_{k}=\beta_{z} \mu_{s} \mu_{z} w_{0}$,

where $W_{k}$ is the standard wind load $\left(\mathrm{kN} / \mathrm{m}^{2}\right) ; w_{0}$ is the basic wind pressure $\left(\mathrm{kN} / \mathrm{m}^{2}\right) ; \beta_{\mathrm{z}}$ is the wind vibration coefficient at height $z ; \mu_{\mathrm{s}}$ is the wind load shape factor; $\mu_{\mathrm{z}}$ is height variation coefficient of wind pressure.

According to the Load Code for the Design of Building Structures, $\mu_{\mathrm{s}}=0.8, \mu_{\mathrm{z}}=0.74, \beta_{\mathrm{z}}=1$ and $\gamma=1.4$. The designed wind loads under different wind pressures are listed in Tab. 8. Tab. 9 shows the wind load $\mathrm{q}$ at the top of different walls.

For the wind load acting on the wall, the root bending moment is calculated by the inverted triangle method. The root bending moment calculation model is illustrated in Fig. 6, and the wall root stress is expressed in Eq. (5).

$M=\frac{1}{2} q H \times \frac{2}{3} H=\frac{1}{3} q H^{2}$.

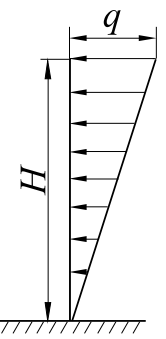

Figure 6 Calculation diagram under the impact of wind loads

The wall should meet the following conditions:

$M<[M]$.

There is:

$H=\sqrt{\frac{3[M]}{q}}$,

where $[M]$ is the allowable bending moment obtained based on the test data; $H$ is the height limit.

Substitute the test results to calculate the brickwork height limit of each wall under the action of wind load (Tab. 10).

It can be seen from Tab. 10 that the height limit is merely $2.5 \mathrm{~m}$ for a cavity wall without connecting structures on the top under the direct impact from the 50year return period wind. The limit is lower than the height 
of general buildings. Therefore, connecting structures or anti-wind columns should be installed on each floor if the cavity wall-enclosed building is located in a region with large wind pressure. This measure is of great necessity for the prevention of out-of-plane damages.

\subsection{Height limit controlled by in-plane shear strength under the impact of earthquakes \\ 3.3.1 Shear strength}

According to the stepped damages in the in-plane test, the shear strength formula and the shear strength of the test are as follows:

$f_{v}=\frac{\sum F_{U}}{A}$.

Similar to the calculation method for seismic action, the bottom shear method is adopted for calculating the shear strength:

$F_{V}=0.85 \alpha G=0.85 \alpha \rho \mathrm{AHg}$,

$$
H=\frac{F_{V}}{0.85 \alpha \rho g A}
$$

where $\alpha$ is the horizontal earthquake influence coefficient, $\rho$ is density of the wall, $A$ is cross-sectional area, $H$ is height, and $g$ is acceleration of gravity.

Table 11 Shear strength of masonry measured in in-plane tests

\begin{tabular}{|c|c|c|c|c|}
\hline \multirow{2}{*}{ Parameters } & \multicolumn{4}{|c|}{ Number of specimens } \\
\cline { 2 - 5 } & $\mathrm{K} 1$ & $\mathrm{~K} 2$ & $\mathrm{~K} 3$ & $\mathrm{~S} 1$ \\
\hline $\mathrm{A}\left(\mathrm{mm}^{2}\right)$ & 16427 & 21427 & 19064 & 41200 \\
\hline $\begin{array}{c}\text { Ultimate } \\
\text { intensity } N\end{array}$ & 2609 & 4411 & 6267 & 15225 \\
\hline$f_{v}(\mathrm{MPa})$ & 0,16 & 0,21 & 0,33 & 0,37 \\
\hline
\end{tabular}

The brickwork height limits under different seismic intensities are calculated based on the wall strengths measured by the test (Tab. 12). It is learned that the height limits are far greater than the allowable out-of-plane values. Thus, the limit wall height is dependent on out-ofplane stress.

Table 7 Height limits under different earthquake intensities

\begin{tabular}{|c|c|c|c|c|c|c|c|c|c|c|}
\hline \multirow{2}{*}{ Earthquake magnitude } & \multirow{2}{*}{ Parameters } & \multicolumn{9}{|c|}{ Number of wall } \\
\hline & & W1A & W1B & W1C & W2A & W2B & W2C & W3A & W3B & $\mathrm{W} 3 \mathrm{C}$ \\
\hline \multirow{6}{*}{6} & $\mathrm{mg} / \mathrm{H}(\mathrm{N} / \mathrm{m})$ & 3285 & 3285 & 4285 & 3812 & 3812 & 4812 & 8240 & 8240 & 12360 \\
\hline & $A$ & 0,04 & 0,04 & 0,04 & 0,04 & 0,04 & 0,04 & 0,04 & 0,04 & 0,04 \\
\hline & $q(\mathrm{~N} / \mathrm{m})$ & 171 & 171 & 232 & 198 & 198 & 250 & 428 & 428 & 624 \\
\hline & {$[M]$} & 4900 & 13986 & 980 & 4900 & 8232 & 6270 & 1920 & 14406 & 13320 \\
\hline & $H(\mathrm{~m})$ & 2 & 3 & 2 & 2 & 3 & 2 & 2 & 3 & 2 \\
\hline & Height limit (m) & 7,57 & 12,79 & 2.97 & 7,03 & 9,11 & 7,08 & 2,99 & 8,20 & 6,44 \\
\hline \multirow{6}{*}{7} & $\mathrm{~m} / \mathrm{H}(\mathrm{N} / \mathrm{m})$ & 3285 & 3285 & 4285 & 3812 & 3812 & 4812 & 8240 & 8240 & 12360 \\
\hline & $\alpha$ & 0,08 & 0,08 & 0,08 & 0,08 & 0,08 & 0,08 & 0,04 & 0,04 & 0,04 \\
\hline & $q(\mathrm{~N} / \mathrm{m})$ & 342 & 342 & 446 & 397 & 397 & 501 & 856 & 856 & 1285 \\
\hline & {$[M]$} & 4900 & 13986 & 980 & 4900 & 8232 & 6270 & 1920 & 14406 & 13320 \\
\hline & $H(\mathrm{~m})$ & 2 & 3 & 2 & 2 & 3 & 2 & 2 & 3 & 2 \\
\hline & Height limit (m) & 5,35 & 9,04 & 2,09 & 4,97 & 6,44 & 5,00 & 2,11 & 5,79 & 4,55 \\
\hline \multirow{6}{*}{8} & $\mathrm{~m} / \mathrm{H}(\mathrm{N} / \mathrm{m})$ & 3285 & 3285 & 4285 & 3812 & 3812 & 4812 & 8240 & 8240 & 12360 \\
\hline & $\alpha$ & 0,16 & 0,16 & 0,16 & 0,16 & 0,16 & 0,16 & 0,04 & 0,04 & 0,04 \\
\hline & $q(\mathrm{~N} / \mathrm{m})$ & 683 & 683 & 891 & 796 & 793 & 1001 & 1713 & 1713 & 2570 \\
\hline & {$[M]$} & 4900 & 13986 & 980 & 4900 & 8232 & 6270 & 1920 & 14406 & 13320 \\
\hline & $H(\mathrm{~m})$ & 2 & 3 & 2 & 2 & 3 & 2 & 2 & 3 & 2 \\
\hline & Height limit (m) & 3,79 & 6,39 & 1,48 & 3,51 & 4,56 & 3,53 & 1,49 & 4,10 & 3,21 \\
\hline \multirow{6}{*}{9} & $\mathrm{~m} / \mathrm{H}(\mathrm{N} / \mathrm{m})$ & 3285 & 3285 & 4285 & 3812 & 3812 & 4812 & 8240 & 8240 & 12360 \\
\hline & $\alpha$ & 0,32 & 0,32 & 0,32 & 0,32 & 0,32 & 0,32 & 0,04 & 0,04 & 0,04 \\
\hline & $q(\mathrm{~N} / \mathrm{m})$ & 1367 & 1367 & 1783 & 1586 & 1586 & 2002 & 3427 & 3427 & 5141 \\
\hline & {$[M]$} & 4900 & 13986 & 980 & 4900 & 8232 & 6270 & 1920 & 14406 & 13320 \\
\hline & $H(\mathrm{~m})$ & 2 & 3 & 2 & 2 & 3 & 2 & 2 & 3 & 2 \\
\hline & Height limit (m) & 2,68 & 4,52 & 1,04 & 2,48 & 3,22 & 2,5 & 1,06 & 2,89 & 2,27 \\
\hline
\end{tabular}

Table 8 Wind loads under different basic wind pressures

\begin{tabular}{|l|c|c|c|c|}
\hline Basic wind pressure $\left(\mathrm{kN} / \mathrm{m}^{2}\right)$ & 0,25 & 0,30 & 0,35 & 0,40 \\
\hline Nominal value of wind loads $\left(\mathrm{kN} / \mathrm{m}^{2}\right)$ & 0,15 & 0,18 & 0,45 & 0,21 \\
\hline Given wind loads $\left(\mathrm{kN} / \mathrm{m}^{2}\right)$ & 0,21 & 0,25 & 0,24 & 0,27 \\
\hline
\end{tabular}

Table 9 Wind loads at the top of walls

\begin{tabular}{|c|c|c|c|c|c|c|c|c|c|c|}
\hline \multicolumn{2}{|c|}{ Number of wall } & W1A & W1B & W1C & W2A & W2B & W2C & W3A & W3B & W3C \\
\hline Breadth $(\mathrm{m})$ & 2 & 2 & 3 & 2 & 2 & 3 & 2 & 2 & 3 \\
\hline \multirow{4}{*}{$\begin{array}{c}\text { Wind loads at the top of walls } \\
q(\mathrm{kN} / \mathrm{m})\end{array}$} & $0,25\left(\mathrm{kN} / \mathrm{m}^{2}\right)$ & 0,76 & 0,76 & 1,08 & 0,76 & 0,76 & 1,08 & 0,76 & 0,76 & 1,08 \\
\cline { 2 - 11 } & $0,30\left(\mathrm{kN} / \mathrm{m}^{2}\right)$ & 0,88 & 0,88 & 1,32 & 0,88 & 0,88 & 1,32 & 0,88 & 0,88 & 1,32 \\
\cline { 2 - 10 } & $0,35\left(\mathrm{kN} / \mathrm{m}^{2}\right)$ & 1,06 & 1,06 & 1,59 & 1,06 & 1,06 & 1,59 & 1,06 & 1,06 & 1,59 \\
\cline { 2 - 10 } & $0,40\left(\mathrm{kN} / \mathrm{m}^{2}\right)$ & 1,20 & 1,20 & 1,80 & 1,20 & 1,20 & 1,80 & 1,20 & 1,20 & 1,80 \\
\cline { 2 - 10 } & $0,45\left(\mathrm{kN} / \mathrm{m}^{2}\right)$ & 1,34 & 1,34 & 2,01 & 1,34 & 1,34 & 2,01 & 1,34 & 1,34 & 2,01 \\
\hline
\end{tabular}


Table 10 Height limit of buildings under wind loads

\begin{tabular}{|c|c|c|c|c|c|c|c|c|c|c|}
\hline \multirow{2}{*}{ Basic wind pressure $\left(\mathrm{kN} / \mathrm{m}^{2}\right)$} & \multirow{2}{*}{ Parameters } & \multicolumn{9}{|c|}{ Number of wall } \\
\hline & & W1A & W1B & W1C & W2A & W2B & W2C & W3A & W3B & W3C \\
\hline \multirow{4}{*}{0.25} & $q(\mathrm{~N} / \mathrm{mm})$ & 0,76 & 0,76 & 1,08 & 0,76 & 0,76 & 1.08 & 0,76 & 0,76 & 1,08 \\
\hline & {$[M]$} & 4900 & 13986 & 980 & 4900 & 8232 & 6270 & 1920 & 14406 & 13320 \\
\hline & $h(\mathrm{~mm})$ & 206 & 206 & 206 & 270 & 270 & 270 & 206 & 206 & 206 \\
\hline & $H(\mathrm{~mm})$ & 4398 & 7430 & 1650 & 4398 & 5700 & 4173 & 2753 & 7541 & 6083 \\
\hline \multirow{4}{*}{0.30} & {$[M]$} & 4900 & 13986 & 980 & 4900 & 8232 & 6270 & 1920 & 14406 & 13320 \\
\hline & $q(\mathrm{~N} / \mathrm{mm})$ & 0,88 & 0,88 & 1,32 & 0,88 & 0,88 & 1,32 & 0,88 & 0,88 & 1,32 \\
\hline & $h(\mathrm{~mm})$ & 206 & 206 & 206 & 270 & 270 & 270 & 206 & 206 & 206 \\
\hline & $H(\mathrm{~mm})$ & 4087 & 6905 & 1492 & 4087 & 5297 & 3775 & 2558 & 7008 & 5002 \\
\hline \multirow{4}{*}{0.35} & $q(\mathrm{~N} / \mathrm{mm})$ & 1,06 & 1,06 & 1,59 & 1,06 & 1,06 & 1,59 & 1,06 & 1,06 & 1,59 \\
\hline & {$[M]$} & 4900 & 13986 & 980 & 4900 & 8232 & 6270 & 1920 & 14406 & 13320 \\
\hline & $h(\mathrm{~mm})$ & 206 & 206 & 206 & 270 & 270 & 270 & 206 & 206 & 206 \\
\hline & $H(\mathrm{~mm})$ & 3723 & 6290 & 1360 & 3724 & 24827 & 3440 & 2331 & 6385 & 5013 \\
\hline \multirow{4}{*}{0.40} & {$[M]$} & 4900 & 13986 & 980 & 4900 & 8232 & 6270 & 1920 & 14406 & 13320 \\
\hline & $q(\mathrm{~N} / \mathrm{mm})$ & 1,20 & 1,20 & 1,80 & 1,20 & 1,20 & 1,80 & 1,20 & 1,20 & 1,80 \\
\hline & $h(\mathrm{~mm})$ & 206 & 206 & 206 & 270 & 270 & 270 & 206 & 206 & 206 \\
\hline & $H(\mathrm{~mm})$ & 3500 & 5913 & 1278 & 3500 & 4537 & 3232 & 2191 & 6001 & 4712 \\
\hline \multirow{4}{*}{0.45} & $q(\mathrm{~N} / \mathrm{mm})$ & 1,34 & 1,34 & 2,01 & 1,34 & 1,34 & 2,01 & 1,34 & 1,34 & 2,01 \\
\hline & {$[M]$} & 4900 & 13986 & 980 & 4900 & 8232 & 6270 & 1920 & 14406 & 13320 \\
\hline & $h(\mathrm{~mm})$ & 206 & 206 & 206 & 270 & 270 & 270 & 206 & 206 & 206 \\
\hline & $H(\mathrm{~mm})$ & 3312 & 5596 & 1210 & 3312 & 4290 & 3059 & 2073 & 5679 & 4458 \\
\hline
\end{tabular}

Table 12 Height limits under earthquake

\begin{tabular}{|c|c|c|c|c|c|}
\hline Fortification intensity of earthquake & Parameters & K1 & K2 & K3 & S1 \\
\hline \multirow{4}{*}{6} & Ultimate load & 2609 & 4411 & 6267 & 15225 \\
\cline { 2 - 6 } & $\mathrm{mg} / \mathrm{H}(\mathrm{N} / \mathrm{m})$ & 3285 & 4285 & 3812 & 8240 \\
\cline { 2 - 6 } & $\alpha$ & 0,04 & 0,04 & 0,04 & 0,04 \\
\cline { 2 - 6 } & Height limit (m) & 23,3 & 30,3 & 48,3 & 54,3 \\
\hline \multirow{4}{*}{7} & Ultimate load & 2609 & 4411 & 6267 & 15225 \\
\cline { 2 - 6 } & $\mathrm{m} / \mathrm{H}(\mathrm{N} / \mathrm{m})$ & 3285 & 4285 & 3812 & 8240 \\
\cline { 2 - 6 } & $\alpha$ & 0,08 & 0,08 & 0,08 & 0,08 \\
\cline { 2 - 6 } & Height limit (m) & 11,6 & 15,1 & 24,1 & 27,2 \\
\hline \multirow{4}{*}{8} & Ultimate load & 2609 & 4411 & 6267 & 15225 \\
\cline { 2 - 6 } & m/H(N/m) & 3285 & 4285 & 3812 & 8240 \\
\cline { 2 - 6 } & $\alpha$ & 0,16 & 0,16 & 0,16 & 0,16 \\
\cline { 2 - 6 } & Height limit (m) & 5,8 & 7,6 & 12,1 & 13,6 \\
\hline \multirow{4}{*}{9} & Ultimate load & 2609 & 4411 & 6267 & 15225 \\
\cline { 2 - 6 } & m/H(N/m) & 3285 & 4285 & 3812 & 8240 \\
\cline { 2 - 6 } & $\alpha$ & 0,32 & 0,32 & 0,3 & 0,32 \\
\cline { 2 - 6 } & Height limit (m) & 2,9 & 3,78 & 6,0 & 6,79 \\
\hline
\end{tabular}

Table 13 Suggested height limits

\begin{tabular}{|c|c|c|c|c|}
\hline Height limit & Earthquake magnitude and wind pressure & Building method I & Building method II & Solid wall \\
\hline \multirow{4}{*}{ Height limit under earthquake (m) } & 6 & 5,0 & 4,7 & 2,0 \\
\hline & 7 & 3,6 & 3,3 & 1,4 \\
\hline & 8 & 2,5 & 2,3 & 0,9 \\
\hline & 9 & 1,8 & 1,7 & 0,7 \\
\hline \multirow{5}{*}{ Height limit under wind loads (m) } & 0,25 & 3,1 & 3,0 & 2,0 \\
\hline & 0,30 & 2,9 & 2,7 & 1,8 \\
\hline & 0,35 & 2,7 & 2,5 & 1,7 \\
\hline & 0,40 & 2,5 & 2,3 & 1,6 \\
\hline & 0,45 & 2,3 & 2,1 & 1,5 \\
\hline
\end{tabular}

\subsection{Suggested height limits}

Aiming to control the minimum height limit and taking account of the wall mass discretization and possibility of overload, the safety coefficient of seismic action is increased 1.5 times; the partial coefficient of wind load is set as 1.4 and the wind pressure height coefficient is temporarily set as $10 \mathrm{~m}$. No additional safety coefficient is needed because the temporary value is relatively large and the wind load is unidirectional, i.e. no instantaneous collapse will occur under the cracking- induced vibration. Tab. 13 lists the recommended height limits.

Tab. 13 shows the brickwork height limits of cavity walls with no buttress column or connecting structure. Once the height exceeds the limit, connecting structures should be installed. From the data in Tab. 13, it is inferred that the height limit in regions with seismic fortification intensities of 8 and 9 is lower than the height of a singlestory house. Hence, the cavity wall is not recommended for regions with seismic fortification intensities of 8 and above, provided that no connecting structure is installed. 
While the basic wind pressure is above $0.4 \mathrm{kN} / \mathrm{m}^{2}$ in most regions in China, the height limit under wind load is lower than the height of a single-story house. If there is no connecting structure, the cavity wall faces the risks of cracking and tilting. To sum up, the enclosure walls of ancient buildings should be protected with independent support structures like buttress columns. The antique columns should be made of wood or reinforced concrete, and should be firmly rooted in the foundation.

\section{Conclusion}

This paper conducts the experimental study and theoretical analysis on the out-of-plane and in-plane stress performance of the cavity wall in antique buildings. In total, 13 groups of cavity walls are subjected to the tests on out-of-plane stress and in-plane stress performance. The research mainly aims at disclosing the effect of bricklaying method, height-width ratio and widththickness ratio on the ultimate bearing capacity and deformation properties of the cavity wall. The following conclusions are drawn through the relevant experimental research and theoretical analysis: the height limit of the continuously laid brickwork no shorter than $2 \mathrm{~m}$ can be controlled according to Tab. 13; if the height exceeds the limit, connecting structures or anti-wind columns should be installed. For the cavity wall brickwork, the out-ofplane load condition is more dangerous than in-plane load condition, and is the control factor of height limit. The wind load has a more obvious impact on the cavity wall enclosure structure than the seismic action. It is recommended to set up an independent anti-wind support structure for cavity wall enclosure structure.

\section{Acknowledgements}

This research is supported by the National Natural Science Foundation of China $(51138002,51378116)$, the National Technology Support Program of China (20128BAK14B05) and the Scientific Research Foundation of the Graduate School of Southeast University (YBJJ1415).

\section{References}

[1] Fang, D. P.; Iwasaki, S.; Yu, M. H.; Shen, Q. P.; Miyamoto, Y.; Hikosaka, H. Ancient Chinese timber architecture. I: Experimental study. // Journal of Structural EngineeringAsce. 127, 11(2001), pp. 1348-1357. https://doi.org/10.1061/(ASCE)0733-9445(2001)127:11(1348)

[2] Fang, D. P.; Iwasaki, S.; Yu, M. H.; Shen, Q. P.; Miyamoto, Y.; Hikosaka, H. Ancient Chinese timber architecture.II: Dynamic characteristics. // Journal of Structural Engineering-Asce. 127, 11(2001), pp. 1358-1364. https://doi.org/10.1061/(ASCE)0733-9445(2001)127:11(1358)

[3] Zhang, S. M.; Lu, R. Q. ICA(3)D - Intelligent computeraided ancient Chinese architecture design. // Advanced Engineering Informatics. 26, 4(2012), pp. 705-715. https://doi.org/10.1016/j.aei.2012.04.002

[4] Mazzeo, R.; Cam, D.; Chiavari, G.; Fabbri, D.; Ling, H.; Prati, S. Analytical study of traditional decorative materials and techniques used in Ming Dynasty wooden architecture. The case of the Drum Tower in Xi'an, PR of China. // Journal of Cultural Heritage. 5, 3(2004), pp. 273-283. https://doi.org/10.1016/j.culher.2004.06.001
[5] Yin, W. D.; Yamamoto, H.; Yin, M. F.; Gao, J.; Trifkovic, S. Estimating the Volume of Large-Size Wood Parts in Historical Timber-Frame Buildings of China: Case Study of Imperial Palaces of the Qing Dynasty in Shenyang. // Journal of Asian Architecture and Building Engineering. 11, 2(2012), pp. 321-326. https://doi.org/10.3130/jaabe.11.321

[6] Hu, T. F.; Lee, S. C.; Cao, J. J.; Ho, W. K.; Ho, K.F.; Chow, J. C. Atmospheric deterioration of Qin brick in an environmental chamber at Emperor Qin's Terracotta Museum, China. // Journal of Archaeological Science. 36, 11 (2009), pp. 2578-2583 https://doi.org/10.1016/j.jas.2009.07.014

[7] Yang, F. W.; Zhang, B. J.; Ma, Q. L. Study of Sticky RiceLime Mortar Technology for the Restoration of Historical Masonry Construction. // Accounts of Chemical Research. 43, 6(2010), pp. 936-944. https://doi.org/10.1021/ar9001944

[8] Qi,W.; Ma, G. Y.; He, L. Y.; Sheng, X. F. Characterization of bacterial community inhabiting the surfaces of weathered bricks of Nanjing Ming city walls. // Science of the Total Environment. 409, 4(2011), pp. 756-762. https://doi.org/10.1016/j.scitotenv.2010.11.001

[9] Lu, W. D.; Deng, D. L.; Ju, X. P.; Chen, X. W.; Yang, H. F. Distribution of timber structures in China and seismic damages analysis. // Journal of Xian University of Architecture \& Technology. (Natural Science Edition). 43, 4(2011), pp. 464-469.

[10] Ge, X. L.; Yu, W.; Zhu, L. X. Earthquake and Typhoon Disaster and Defense Measures of Cacity-wall Building in Town and Village. // Earthquake Resistant Engineering and Retrofitting. 33, 2(2011), pp. 143-149.

[11] GB 50011-2001. Code for Seismic Design of Building. Beijing: China Building Industry Press; 2008.

[12] Zhou, B. Z. Experiences and future of earthquake-resisting of the masonry structure in China. // Building Structure. 41, 9(2011), pp. 151-158.

[13] Center GEES. Seismic Safety Evaluation Report of Guangzhou Pazhou PZB1301 Building Project. 2008. p. 10.

[14] Zhou, L. P. Study on the seismic performance and reinforcement measures of cavity wall masonry structure. Hebei University of Engineering, Hebei, 2012. (in Chinese)

[15] Liu, C. M.; Feng, W.; Yang, L. R. Studies on the earthquake-resistant capability and the strengthening of cavity wall buildings. // Journal of Scismology. 2(1990), pp. 10-15.

[16] Shang, S. P.; Lei, M.; Feng J. C.; Yue, X. Y. Experimental study on shear behaviour and finite element analysis of row lock wall. // Journal of Earthquake Engineering and Engineering Vibration. 33(2013), pp. 87-96.

[17] Liu, Y. Z. Study on Strengthening and Seismic Performance of Rowlock Cavity Wall Buildings. North China University of Technology, Xi'an, 2016.

[18] Zhao, P.; Jackson, M. D.; Zhang, Y. S. Material Characteristics of Ancient Chinese Lime Binder and Experimental Reproductions with Organic Admixtures. // Construction and Building Materials. 84, (2015), pp. 477488. https://doi.org/10.1016/j.conbuildmat.2015.03.065

[19] Ellingwood, B. R.; Rosowsky, D. V.; Li, Y.; Kim, J. H. Fragility assessment of light-frame wood construction subjected to wind and earthquake hazards. // Journal of Structural Engineering-Asce. 130, 12(2004), pp. 1921-1930. https://doi.org/10.1061/(ASCE)0733-9445(2004)130:12(1921)

[20] Tomasi, R.; Sartori, T. Mechanical behaviour of connections between wood framed shear walls and foundations under monotonic and cyclic load. // Construction and Building Materials. 44, (2013), pp. 682690. https://doi.org/10.1016/j.conbuildmat.2013.02.055

[21] Olmati, P.; Petrini, F.; Gkoumas, K. Fragility analysis for the Performance-Based Design of cladding wall panels subjected to blast load. // Engineering Structures. 78, (2014), pp. 112-120. https://doi.org/10.1016/j.engstruct.2014.06.004 
[22] Mi, Z. N.; Pan, L. P.; Chen, J. P.; Chen, L. A.; Wu, R. Z. Consecutive lifting and lowering electrohydraulic system for large size and heavy structure. // Automation in Construction. 30, (2013), pp. 1-8.

https://doi.org/10.1016/j.autcon.2012.10.008

[23] Almusallam, T. H.; Al-Salloum, Y. A. Behavior of FRP strengthened infill walls under in-plane seismic loading. // Journal of Composites for Construction. 11, 3(2007), pp. 308-318.

https://doi.org/10.1061/(ASCE)1090-0268(2007)11:3(308)

[24] Dolatshahi, K. M.; Aref, A. J.; Whittaker, A. S; Interaction Curves for In-Plane and Out-of-Plane Behaviors of Unreinforced Masonry Walls. // Journal of Earthquake Engineering. 19, 1(2015), pp. 60-84. https://doi.org/10.1080/13632469.2014.946571

[25] Misir, I. S.; Ozcelik, O.; Kahraman, S. The Behavior of Double-Whyte Hollow Clay Brick Walls under Bidirectional Loads in R/C Frames. // Teknik Dergi. 26, 3(2015), pp. 7139-7165.

\section{Authors' addresses}

Peng Zhao, PhD candidate

College of Materials Science and Engineering, Jiangsu Key Laboratory for Construction Materials, Southeast University, Nanjing 211189, China E-mail: zhaopeng_610@163.com

ShishaoXiong, graduate student

College of Civil and Transportation Engineering, Hohai University, Nanjing 210098, China

E-mail: 1065142296@qq.com

Erjun Wu, associate prof. PhD

College of Civil and Transportation Engineering,

Hohai University, Nanjing 210098, China

E-mail: xiaozhufly9823@163.com

\section{Yunsheng Zhang, prof. PhD}

(Corresponding author)

College of Materials Science and Engineering,

Jiangsu Key Laboratory for Construction Materials,

Southeast University, Nanjing 211189, China

E-mail: zhangyunsheng2011@163.com 